\title{
Gastrointestinal malignancies harbor actionable MET exon 14 deletions
}

\author{
Jeeyun Lee ${ }^{1,2, *}$, Sai-Hong Ignatius $\mathrm{Ou}^{3, *}$, Ji Min Lee ${ }^{4, *}$, Hee Cheol Kim ${ }^{5, *}$, Mineui \\ Hong $^{6}$, Sun Young Kim ${ }^{1}$, Jiryeon Jang ${ }^{1}$, Soomin Ahn ${ }^{6}$, So Young Kang ${ }^{6}$, Sujin Lee ${ }^{1}$, \\ Seung Tae Kim ${ }^{1}$, Bogyou Kim ${ }^{4}$, Jaehyun Choi ${ }^{4}$, Kyung-Ah Kim ${ }^{4}$, Jiyun Lee ${ }^{1}$, Charny Park ${ }^{1,6}$, \\ Se Hoon Park ${ }^{1}$, Joon Oh Park ${ }^{1,2}$, Ho Yeong Lim ${ }^{1}$, Won Ki Kang ${ }^{1}$, Keunchil Park ${ }^{1,2}$, \\ Young Suk Park' ${ }^{1}$, Kyoung-Mee Kim²,6 \\ ${ }^{1}$ Department of Medicine, Division of Hematology-Oncology, Samsung Medical Center, Sungkyunkwan University School of \\ Medicine, Seoul, Korea \\ ${ }^{2}$ Innovative Cancer Medicine Institute, Samsung Medical Center, Seoul, Republic of Korea \\ ${ }^{3}$ Chao Family Comprehensive Cancer Center, University of California Irvine School of Medicine, Orange, California, USA \\ ${ }^{4}$ Samsung Biomedical Research Institute, Samsung Advanced Institute of Technology (SAIT)/Samsung Electronics Co. Ltd, \\ Yeongtong-gu, Suwon-si, Gyeonggi-do, Korea \\ ${ }^{5}$ Department of Surgery, Samsung Medical Center, Sungkyunkwan University School of Medicine, Seoul, Korea \\ ${ }^{6}$ Department of Pathology and Translational Genomics, Samsung Medical Center, Sungkyunkwan University School of \\ Medicine, Seoul, Korea \\ *These authors have contributed equally to this work \\ Correspondence to: \\ Young Suk Park, e-mail: pys27hmo@skku.edu \\ Keunchil Park, e-mail: kpark@skku.edu \\ Kyoung-Mee Kim, e-mail: kkmkys@skku.edu \\ Keywords: MET exon 14 skipping, colorectal carcinoma, MET monoclonal antibodies, crizotinib, gastrointestinal malignancies \\ Received: May 19, 2015 \\ Accepted: August 31, 2015 \\ Published: September 10, 2015
}

\section{ABSTRACT}

Recently, MET exon 14 deletion (METex14del) has been postulated to be one potential mechanism for MET protein overexpression. We screened for the presence of METex14de/ transcript by multiplexed fusion transcript analysis using nCounter assay followed by confirmation with quantitative reverse transcription PCR with correlation to MET protein expression by immunohistochemistry (IHC) and MET amplification by fluorescence in situ hybridization (FISH). We extracted RNAs from 230 patients enrolled onto the prospective molecular profiling clinical trial (NEXT-1) (NCT02141152) between November 2013 and August 2014. Thirteen METex14del cases were identified including 3 gastric cancer, 4 colon cancer, 5 non-small cell lung cancer, and one adenocarcinoma of unknown primary. Of these 13 METex14del cases, 11 were MET IHC $3+$ and 2 were 2+. Only one out of the 13 METex14del cases was MET amplified (MET/CEP ratio > 2.0). Growths of two (gastric, colon) METex14del+ patient tumor derived cell lines were profoundly inhibited by both MET tyrosine kinase inhibitors and a monoclonal antibody targeting MET. In conclusion, METex14del is a unique molecular aberration present in gastrointestinal (GI) malignancies corresponding with overexpression of MET protein but rarely with MET amplification. Substantial growth inhibition of METex14del+ patient tumor derived cell lines by several MET targeting drugs strongly suggests METex14del is a potential actionable driver mutation in GI malignancies.

\section{INTRODUCTION}

Aberrations in the hepatocyte growth factor (HGF)mesenchymal-epithelial transition (MET) receptor tyrosine kinase axis are frequent in solid malignancies [1]. One such aberration is the overexpression of the MET protein as determined by immunohistochemistry (IHC) which may be associated with MET amplification. MET amplification is present in about $2.6 \%$ among 1,115 patient tumors assayed [2]. For example, the frequency of $M E T$ amplification is rare 
in gastroesophageal/gastric cancer [3] while MET protein overexpression has been reported in higher incidence [4]. The discordance between low MET amplification and high MET protein expression indicates there are other potential mechanisms that can lead to MET overexpression. One such mechanism is MET exon14 deletion (METex14del) where part of the transmembrane portion and region for the Casitas B-lineage lymphoma (Cbl) E3 ligase-mediated degradation is deleted leading to delay degradation of MET and hence its overexpression (Supplementary Figure S1) [5, 6].

METex14del was initially described in 2006 in non-small cell lung cancer (NSCLC) and was caused by mutation in the splice donor site in intron 14 and intronic sequence deletions around MET exon 14 [5]. The presence of METex14del in NSCLC has subsequently been confirmed by RNA sequencing and whole genome sequencing $[7,8]$. Additionally, METex14del has been reported in gastric cancer (GC) cell line Hs746T [9, 10] and neuroblastoma [11] indicating this is a potential common mechanism for a variety of tumors to delay the ubiquitination and downregulation of MET protein leading to its overexpression [5].
We investigated patients with metastatic solid malignancies primarily gastrointestinal (GI) and lung malignancies for the presence of METex14del using multiplexed fusion transcript detection assay and then confirmed with reverse transcription PCR (RT-PCR) correlated the MET protein expression and MET amplification in METex $14 \mathrm{del}+$ cases. We further generated patient derived tumor cell lines and screened them for the presence of METex $14 \mathrm{del}$ and investigated the consequence of MET inhibition in these METex14del+ cells lines.

\section{RESULTS}

The patient cohort from the NEXT-1 trial (NCT02141152), which is an actively enrolling clinical trial for genomic profiling in cancer patients, was used (Figure 1). Of 428 patients enrolled and screened, sufficient RNAs for multiplexed fusion transcript detection analysis by nCounter assay were available in 230 patients (Table 1). The detailed probe design for multiplexed fusion transcript assay surveying for ALK, ROS1, RET,

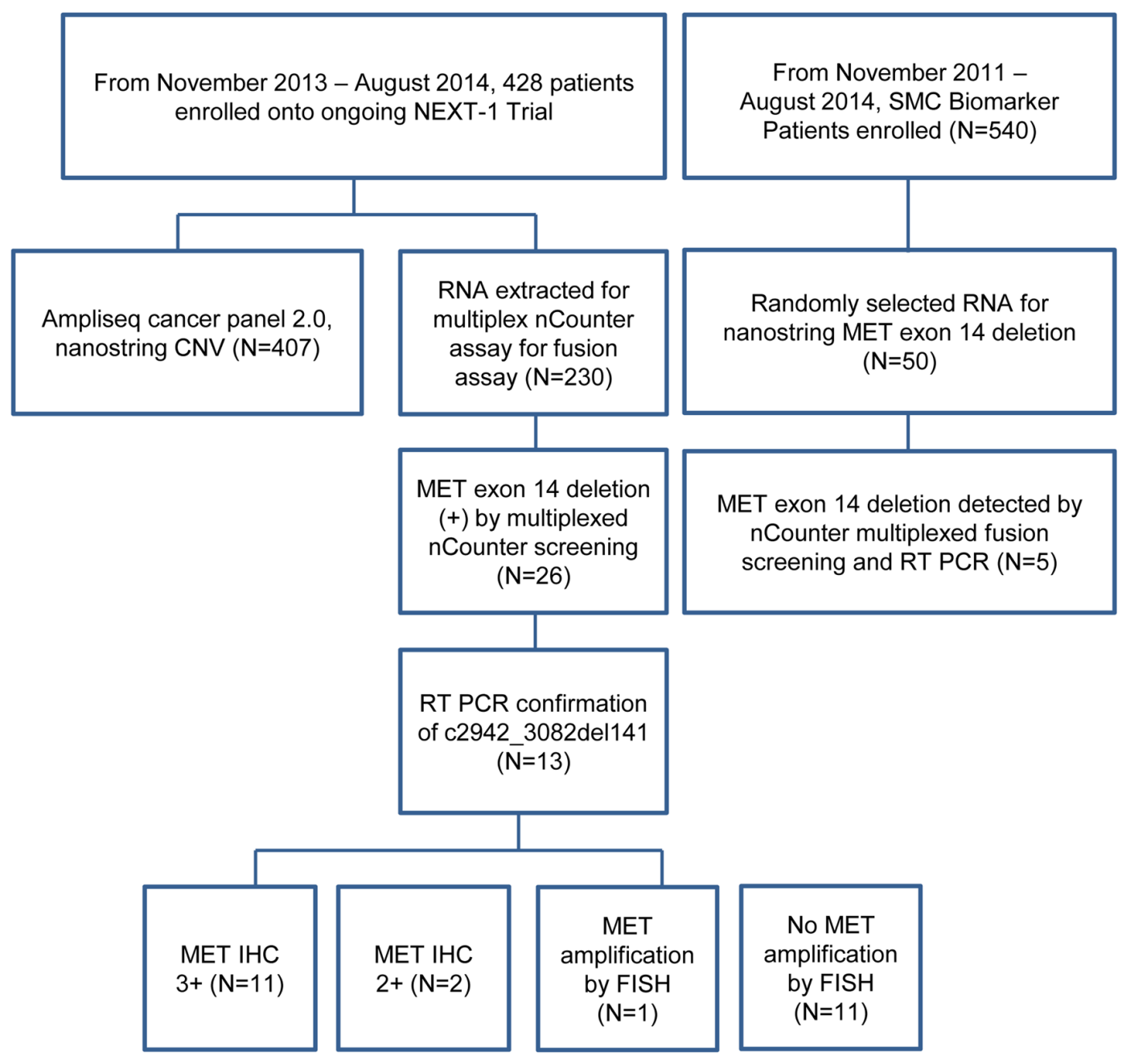

Figure 1: Study flow chart. 
Table 1: Patient characteristics

\begin{tabular}{|c|c|c|}
\hline Variable & $N(\%)$ & MET exon 14 deletion ( + ) \\
\hline \multicolumn{3}{|c|}{ Patient tumor specimens $(N=230)$} \\
\hline \multicolumn{3}{|l|}{ Age-year } \\
\hline Median & 57 & \\
\hline Range & $20-87$ & \\
\hline \multicolumn{3}{|l|}{ Sex, no. (\%) } \\
\hline Male & 134 & \\
\hline Female & 96 & \\
\hline Stage & $230(100)$ & \\
\hline \multicolumn{3}{|l|}{ Tumor type, no. $(\%)^{* * *}$} \\
\hline Gastric cancer & 42 & $3(7.1)$ \\
\hline NSCLC & 51 & $5(9.8)$ \\
\hline Colon cancer & 43 & $4(9.3)$ \\
\hline Rectal cancer & 23 & $0(0.0)$ \\
\hline Hepatocellular carcinoma & 15 & $0(0.0)$ \\
\hline Sarcoma & 9 & $0(0.0)$ \\
\hline Pancreatic cancer & 5 & $0(0.0)$ \\
\hline Cholangiocarcinoma & 6 & $0(0.0)$ \\
\hline Melanoma & 5 & $0(0.0)$ \\
\hline ACUP* & 3 & $1(33.3)$ \\
\hline Esophageal squamous carcinoma & 1 & $0(0.0)$ \\
\hline Renal cell carcinoma & 1 & $0(0.0)$ \\
\hline Others & 15 & $0(0.0)$ \\
\hline
\end{tabular}

Patient Derived Cells $(N=50)$

\begin{tabular}{|l|c|c|}
\hline Patient derived cells $(\boldsymbol{N}=\mathbf{5 0})$ & & 1 \\
\hline Gastric cancer & 22 & 1 \\
\hline Colon cancer & 5 & 1 \\
\hline NSCLC & 4 & 1 \\
\hline Melanoma & 2 & 0 \\
\hline Cholangiocarcioma & 3 & 0 \\
\hline HCC** & 4 & 1 \\
\hline Duodenal carcinoma & 1 & 0 \\
\hline Esophageal squamous cell & 1 & 0 \\
\hline Sarcoma and other rare cancer & 8 & \multicolumn{2}{|c|}{} \\
\hline
\end{tabular}

*(Adenocarcinoma of unknown primary had met exon 14 skipping and MET amplification).

**HCC, hepatocellular carcinoma.

***219 included for final analysis from 230 . 
NTRK1, and NTRK3 is provided in Supplementary Table S1. Of the multiplexed fusion assay, a nanostring probe to detect any $141 \mathrm{bp}$ METex14del transcript (p.982_1028del47, c.2942 (Supplementary Table S1) was included. Of the 230 tumor specimens screened, 86 specimens were freshly frozen tissues and 144 specimens were from formalin-fixed paraffin-embedded (FFPE) tissues. In parallel, we screened fifty patient derived tumor cell (PDC) lines generated from the SMC Biomarker study (NCT01831609) for METex14del. The SMC Oncology Biomarker study is an ongoing study which enrolls metastatic solid cancer patients with malignant ascites, malignant pleural effusion, endoscopic biopsies or surgical specimens for PDC model establishments (Figure 1 for Study Flow Chart).

Of the 230 tumor cohort ( 86 fresh frozen tissue and 144 formalin-fixed paraffin-embedded tissues), 219 were finally included in the analysis as 11 samples failed to pass QC (quality control). With initial screening of multiplexed nCounter fusion transcript analysis, 26 were detected as potential positive cases for METex14del with high fusion transcript mRNA expression (Supplementary Figure S2) and $13(5.7 \%)$ patients were eventually confirmed to be METex $14 d e l+$ by quantitative reverse transcriptasepolymerase chain reaction (RT-PCR): 3 gastric carcinoma (GC), 4 colon, 5 non-small cell lung cancer (NSCLC) and one adenocarcinoma of unknown primary (ACUP). Among these 13 METex 14 del cases, 11 cases were MET IHC $3+$ and 2 cases were MET IHC 2+. Only one of the 13 METex $14 d e l+$ cases had concomitant MET amplifications (Table 2). All METex14del cases were negative for ALK, ROS1, RET, NTRK1, and NTRK3 fusion.

All 13 METex14del cases were further confirmed by qualitative RT-PCR using probes overlapping an exon 13-15 junction, a fusion transcript caused by exon 14 skipping. In all cases, although the absolute $\mathrm{Ct}$ (cycles to threshold) values of RT-PCR showed relatively high around 32, there was definite amplification of target sequences. Deep sequencing targeting whole $M E T$ gene including intron using DNAs from GI cancers, there were many mutations in the introns (Table 3). Interestingly, all our GI samples harbored c.3082+811A TTTTAACA > GGTTTGAT mutations on intron 14 region of MET.

A total of 3 out of $42 \mathrm{GC}$ patients were METex $14 \mathrm{del}$ positive (Table 3). All GC cases were MET IHC $3+$ and the only case in the series with MET amplification. For example, one case was a 27 -year old male patient who presented with poorly differentiated adenocarcinoma and massive malignant ascites and died shortly after diagnosis. His tumor showed strong MET overexpression by IHC $(3+)$ but no MET amplification by FISH (Figure $2 \mathrm{a}$ and $2 \mathrm{~b}$ (with both amplification and METex 14+), Table 3). PDC cell lines were generated from his malignant ascites and investigated for anti-tumor activity by MET inhibitors (below). The second METex14del case was a 67 -year old male patient who also presented with poorly differentiated adenocarcinoma with concomitant $M E T$ amplification (MET/CEP7 12.8) and strong MET overexpression. For colon cancer, 4 patients were METex $14 \mathrm{del}$ positive (Tables 2 and 3). All of the METex14del+ (or positive) colon cancer patients were not $M E T$ amplified and all but one were MET IHC $3+$. KRAS was wild-type in all 4 colon cancer patients but BRAF V600E was detected in two of the 4 cases. Interestingly, all 4 colon cancer METex 14+cases were left-sided colon cancer. For NSCLC, 5 of $51(9.8 \%)$ patients were METex $14 \mathrm{del}+$ and none of the patients had concomitant $M E T$ amplifications. The median age for the five patients was 49 years and four patients $(80 \%)$ were never-smokers (Table 2). Of the METex14del + NSCLC patients, one patient had concomitant EGFR deletion mutation in exon 19 and T790M within exon 20. None of the METex14del NSCLC patients had concomitant KRAS mutations or MET amplification.

\section{METex14del patient derived tumor cell lines}

We identified 5 with high METex14 transcript expressions and further confirmed by RT-PCR (Table 1, Supplementary Figure S2). Of the 5 PDC cell lines, four METex $14 \mathrm{del}+$ cell lines were tested for potential antitumor efficacy of c-MET inhibitors, crizotinib (small molecule) and SAIT301 (monoclonal antibody) [6]. In Figure 3D, the expressions of MET protein in GC and CRC PDC cell lines were confirmed using Western blot analysis. Crizotinib, a small molecule targeting MET as well as ALK [12-14], led to dose-dependent growth inhibition both in GC and CRC PDCs (Figure 3A). We further tested otherMET inhibitors such as PHA-665752 and cabozantinib (XL184) (Supplementary Figure 3A and 3B); PHA-665752 is a small molecule inhibitor that specifically targets MET, and cabozantinib is a small molecule inhibitor that targets the MET, VEGFR2, and Ret kinases [15]. PHA-665752 and cabozantinib demonstrated potent growth inhibition in METex14+ GC and CRC PDCs whereas lapatinib, an EGFR and HER2 inhibitor, and cetuximab (Erbitux), an EGFR targeting monoclonal antibody exhibited no such effects (Supplementary Figure S3C). Other PDC line data including melanoma and esophageal squamous cell carcinoma are provided in Supplementary Figure S4. Taken together, these experimental results implicate anti-MET drugs specific inhibition of METex14del+ patient derived cell lines.

Previously reported anti-MET antibody, SAIT301 promotes a Cbl-independent MET degradation pathway and internalization of MET without ubiquitination [6]. Splice mutations of exon 14 have been associated with a deletion of the juxtamembrane domain of MET resulting in the loss of interaction with $\mathrm{Cbl}$ and Cbl-dependent MET degradation through ubiquitination. We tested SAIT301 in the METex14del+ GC and CRC PDCs to further confirm its $\mathrm{Cbl}$-independent Met degradation mechanism. As shown in Figure 3B and 3C, SAIT301 
Table 2: Characteristics of MET exon 14 deletion (METex14) patients according to tumor types

\begin{tabular}{|c|c|c|c|c|}
\hline & Colon & Gastric & ACUP & Lung \\
\hline $\mathbf{N}$ & 4 & 3 & 1 & 5 \\
\hline \multicolumn{5}{|l|}{ Age } \\
\hline Median & 63 & 53 & & 49 \\
\hline (range) & $42-87$ & $27-67$ & & $36-60$ \\
\hline \multicolumn{5}{|l|}{ Gender } \\
\hline Male & 2 & 2 & 1 & 1 \\
\hline Female & 2 & 1 & 0 & 4 \\
\hline \multicolumn{5}{|l|}{ Smoking history } \\
\hline Never-smoker & $\mathrm{NC}$ & $\mathrm{NC}$ & $\mathrm{NC}$ & 4 \\
\hline Ever-smoker & & & & 1 \\
\hline \multicolumn{5}{|l|}{ Histology } \\
\hline Adenocarcinoma & 4 & 3 & 1 & 4 \\
\hline Squamous cell & 0 & 0 & 0 & 1 \\
\hline Large cell neuroendocrine & 0 & 0 & 0 & 0 \\
\hline Undifferentiated & 0 & 0 & 0 & 0 \\
\hline \multicolumn{5}{|l|}{ Tumor differentiation } \\
\hline Well & 1 & 0 & 0 & 0 \\
\hline Moderate & 2 & 0 & 0 & 1 \\
\hline Poor & 1 & 3 & 1 & 4 \\
\hline \multicolumn{5}{|l|}{ MET IHC } \\
\hline $\mathbf{0}$ & 0 & 0 & 0 & 0 \\
\hline $1+$ & 0 & 0 & 0 & 0 \\
\hline $2+$ & 1 & 0 & 0 & 0 \\
\hline $3+$ & 3 & 3 & 1 & 5 \\
\hline \multicolumn{5}{|c|}{ Concomitant MET amplification } \\
\hline Yes & 0 & 1 & 0 & 0 \\
\hline No & 4 & 2 & 0 & 5 \\
\hline \multicolumn{5}{|l|}{\begin{tabular}{|l} 
Confirmed by \\
RT-PCR
\end{tabular}} \\
\hline Yes & 4 & 3 & 1 & 5 \\
\hline No & 0 & 0 & 0 & 0 \\
\hline
\end{tabular}

$\mathrm{NC}$, not contributable; wt, wild type.

demonstrated potent growth inhibition of both GC and CRC PDCs whereas 5D5, another bivalent Met targeting antibody, exhibited no proliferation inhibitory effects. To determine antibody mediated down-regulation of MET, we measured the total MET levels in GC and CRC METex14del+ PDCs following SAIT301 treatment
(Figure 3D). SAIT301 antibody dramatically reduced MET protein levels. In addition, phosphorylation of Akt, one of major signaling mediators of MET RTK, was also significantly inhibited by treatment with SAIT301. In conclusion, these results confirm that SAIT301 induces degradation of MET in METex14+ PDCs by 
Table 3: Clinicopathologic characteristics of the gastrointestinal cancer and adenocarcinoma of unknown primary with METex14del

\begin{tabular}{|c|c|c|c|c|c|c|c|c|c|}
\hline $\begin{array}{l}\text { Patient } \\
\text { Number }\end{array}$ & Gender & Age & Site of tumor & Clinical findings & $\begin{array}{l}\text { MET } \\
\text { IHC }\end{array}$ & Nanostring & $\begin{array}{l}\text { MET amplification } \\
\text { (CEP7/MET) }\end{array}$ & $\begin{array}{l}\text { Genetic } \\
\text { alterations }\end{array}$ & $\begin{array}{l}\text { MET variants detected in deep } \\
\text { sequencing }\end{array}$ \\
\hline PS-14-482 & F & 61 & $\begin{array}{l}\text { Descending } \\
\text { colon }\end{array}$ & $\begin{array}{l}\text { Colon cancer } \\
\text { with peritoneal } \\
\text { seeding }\end{array}$ & $2+$ & 173.42 & No (1:1) & $\begin{array}{l} \\
\text { KRAS-wild } \\
\text { BRAF V600E } \\
\text { mutation } \\
\text { Microsatellite- } \\
\text { stable }\end{array}$ & $\begin{array}{l}\text { c. } 3082+811 \text { TTTTAACA }> \\
\text { GGTTTGAT }(0.189) \\
\text { c.3082+115ATTTACCTC }> \\
\text { TTGTTTGTT }(0.095) \\
\text { c.3082+980CTATT }> \\
\text { GATAA }(0.121) \\
\text { c.3083-730del } 1(0.058) \\
\text { c.3083-719TT }>\text { GA }(0.056) \\
\text { c.3083-257AAGCA }> \\
\text { GATCT }(0.053)\end{array}$ \\
\hline PS-14-491 & M & 42 & Sigmoid colon & $\begin{array}{l}\text { Colon cancer } \\
\text { with multiple } \\
\text { lymph node } \\
\text { metastasis }\end{array}$ & $3+$ & 174.29 & No $(1: 1.2)$ & \begin{tabular}{|l|} 
KRAS-wild \\
BRAF-wild \\
TP53 and \\
CTNNB1 \\
mutation \\
Microsatellite- \\
unstable
\end{tabular} & $\begin{array}{l}\text { c.3082+811TTTTAACA > } \\
\text { GGTTTGAT }(0.140) \\
\text { c. } 2941+24 \mathrm{~T}>\mathrm{C}(0.262) \\
\text { c.3082+388TTGA }> \\
\text { AATT }(0.055) \\
\text { c.3082+716T }>\text { C }(0.382) \\
\text { c.3083-1164TTTT }> \\
\text { AGAC }(0.057) \\
\text { c.3083-730del } 1(0.061) \\
\text { c.3083-718TCTCC }> \\
\text { CAGTT }(0.071)\end{array}$ \\
\hline PS-14-536 & M & 87 & $\begin{array}{l}\text { Descending } \\
\text { colon }\end{array}$ & $\begin{array}{l}\text { Colon cancer } \\
\text { with obstruction, } \\
\text { seeding }\end{array}$ & $3+$ & 51.61 & No $(1: 0.9)$ & $\begin{array}{l}\text { KRAS-wild } \\
\text { BRAF-wild } \\
\text { TP53 and } \\
\text { APC mutation }\end{array}$ & $\begin{array}{l}\text { C.3082+811TTTTAACA }> \\
\text { GGTTTGAT }(0.062) \\
\text { c.3082+96A }>\text { G }(0.061) \\
\text { c. } 3082+99 \mathrm{~A}>\mathrm{C}(0.061) \\
\text { c. } 3082+1430 \mathrm{C}>\mathrm{T}(0.094) \\
\text { c.3083-731TAAAAAAAAAAAT }> \\
\text { TAAAAAAAAAAAAT }(0.083) \\
\text { c.3083-730 del }(0.073)\end{array}$ \\
\hline PS-14-549 & F & 62 & $\begin{array}{c}\text { Rectosigmoid } \\
\text { colon }\end{array}$ & $\begin{array}{l}\text { Colon cancer } \\
\text { with distant } \\
\text { metastasis }\end{array}$ & $3+$ & 165.18 & No $(1: 1.1)$ & \begin{tabular}{|l|} 
\\
\\
KRAS-wild \\
BRAF V600E \\
mutation \\
$\begin{array}{l}\text { Microsatellite- } \\
\text { stable }\end{array}$
\end{tabular} & $\begin{array}{l}\text { c.3082+811TTTTAACA }> \\
\text { GGTTTGAT }(0.272) \\
\text { c.3082+63GT }> \\
\text { TC }(0.093) \\
\text { c.3082+69TATT }> \\
\text { TAAGC }(0.089) \\
\text { c.3082+74T }>\text { C }(0.098) \\
\text { c.3082+376GAAGC }> \\
\text { AGCCG }(0.232) \\
\text { c.3082+730TGAGTCA }> \\
\text { CAACATGA }(0.109) \\
\text { c.3082+1061T }>\text { G }(0.278) \\
\text { c.3082+1082GAAAAAAAAC }> \\
\text { GAAAAAAAAAAC }(0.050) \\
\text { c.3083-1342AG }>\text { GT }(0.062) \\
\text { c.3083-1101GGCC }> \\
\text { TTAT }(0.231) \\
\text { c.3083-1070CC }>\text { GT }(0.159) \\
\text { c.3083-1063A }>\text { G }(0.062) \\
\text { c.3083-731TAAAAAAAAAAA }> \\
\text { TAAAAAAAAAAT }(0.081) \\
\text { c.3083-523TACC }> \\
\text { AATT }(0.051) \\
\text { c.3083-330CAATTG }> \\
\text { GAAAAA }(0.054) \\
\text { c.3083-324CT }>\text { TA }(0.052) \\
\text { c.3083-208GGGTAAAA }> \\
\text { ACAGGAAG }(0.054)\end{array}$ \\
\hline PS-14-260 & M & 52 & ACUP & $\begin{array}{l}\text { Multiple lymph } \\
\text { node enlargement } \\
\text { without primary }\end{array}$ & $3+$ & 193.64 & No $(1: 1.4)$ & \begin{tabular}{|l|} 
KRAS-wild \\
BRAF-wild \\
TP53 and \\
STK11 \\
mutation \\
Microsatellite- \\
stable
\end{tabular} & Not tested \\
\hline
\end{tabular}




\begin{tabular}{|c|c|c|c|c|c|c|c|c|c|}
\hline $\begin{array}{l}\text { Patient } \\
\text { Number }\end{array}$ & Gender & Age & Site of tumor & Clinical findings & $\begin{array}{l}\text { MET } \\
\text { IHC }\end{array}$ & Nanostring & $\begin{array}{l}\text { MET amplification } \\
\text { (CEP7/MET) }\end{array}$ & $\begin{array}{c}\text { Genetic } \\
\text { alterations }\end{array}$ & $\begin{array}{l}\text { MET variants detected in deep } \\
\text { sequencing }\end{array}$ \\
\hline PS-14-503 & M & 67 & Gastric & $\begin{array}{l}\text { Gastric cancer } \\
\text { with ascites }\end{array}$ & $3+$ & $\square 121$ & Yes $(1: 12.8)$ & $\begin{array}{l}\text { TP53 p.V73M } \\
\text { mutation }\end{array}$ & $\begin{array}{l}\text { c. } 3082+811 \text { TTTTAACA }> \\
\text { GGTTTGAT }(0.134) \\
\text { c.3082+1082GAAAAAAAAAC }> \\
\text { GAAAAAAAAAAC }(0.055) \\
\text { c.3083-731TAAAAAAAAAAAT }> \\
\text { TAAAAAAAAAAT }(0.089)\end{array}$ \\
\hline PS-14-658 & M & 27 & Gastric & $\begin{array}{l}\text { Gastric cancer } \\
\text { with multiple } \\
\text { lymphadenopathy } \\
\text { and ascites }\end{array}$ & $3+$ & $\square 131$ & No (1:0.75) & $\begin{array}{l}\text { TP53 } \\
\text { p.R141H } \\
\text { mutation } \\
\text { CDH1 } \\
\text { p.G352fs } \\
\text { mutation } \\
\text { Polysomy-7 }\end{array}$ & $\begin{array}{l}\text { c. } 3082+811 \text { TTTTAACA }> \\
\text { GGTTTGAT }(0.070) \\
\text { c.3083-731TAAAAAAAAAAAT }> \\
\text { TAAAAAAAAAAT }(0.117) \\
\text { c.3083-730del }(0.088)\end{array}$ \\
\hline PS-14-875 & $\mathrm{F}$ & 64 & Gastric & $\begin{array}{l}\text { Gastric cancer } \\
\text { with seeding }\end{array}$ & $3+$ & $\square 142$ & No $(1: 1)$ & $\begin{array}{l}\text { PTEN } \\
\text { P.V119D } \\
\text { mutation }\end{array}$ & $\begin{array}{l}\text { c.3082+811TTTTAACA }> \\
\text { GGTTTGAT }(0.113) \\
\text { c.3082+730TGAG }>\text { CAACA }(0.056) \\
\text { c.3082+735C }>\text { G }(0.057) \\
\text { c.3082+1281GCAGAGCTT }> \\
\text { TAAAAGGAG }(0.062) \\
\text { c.3083-1320A }>\text { C }(0.082) \\
\text { c.3083-1317G }>\text { T }(0.082) \\
\text { c.3083-1041GT }>\text { CA }(0.055) \\
\text { c.3083-860GTCAGTTG }> \\
\text { AACACTCAG }(0.068) \\
\text { c.3083 731TAAAAAAAAAAAT }> \\
\text { TAAAAAAAAAAT }(0.113) \\
\text { c.3083-730del1 }(0.075) \\
\text { c.3083-208GGGTAAAA }> \\
\text { ACAGGAAG }(0.087)\end{array}$ \\
\hline
\end{tabular}

down-regulating MET in Cbl-independent manners and subsequent inhibition of tumor cell growth.

\section{MATERIALS AND METHODS}

\section{Patients}

Patients with metastasis of solid cancers were enrolled onto the NEXT-1 trial [NCT\#02141152] at Samsung Medical Center. The study was approved by the institutional review board of the Samsung Medical Center. All study participants provided written informed consent before study entry. Briefly, patients with metastatic solid cancer were eligible to enter the study. From November 2013 to August 2014, 428 patients were enrolled. of 428, 230 patients cohort with available tissue specimens for RNA extractions were included in this screening project.

\section{NanoString-Based multiplexed MET exon 14 deletion and ALK, ROS1, NTRK1, NTRK3 or RET fusion transcripts assay}

We performed nCounter assays (NanoString, Seattle, WA) according to the manufacturer's instruction in duplicate. Total RNA was extracted from fresh tumor tissue (tumor content $>70 \%$ ) or from one to four FFPE tissue sections ( $4 \mu \mathrm{m}$ thick) using the High Pure RNA Paraffin kit (Roche Diagnostic, Mannheim, Germany). After RNA extraction according to the manufacturer's protocol, we added additional DNase treatment. RNA concentration was measured with the Nanodrop 8000 (Thermo-Scientific,
Wilmington, DE) and stored $-80^{\circ} \mathrm{C}$ until use. Briefly, 300 ng of total RNA was hybridized to nCounter probe sets for 16 hours at $65^{\circ} \mathrm{C}$. The target sequence for METex $14 d e l$ transcript was 5'-ATTACTACTTGGGTTTTTCCTGTGG CTGAAAAAGAGAAAGCAAATTAAAGATCAGTTTC CTAATTCATCTCAGAACGGTTCATGCCGACAAGTG CAGTAT (Supplementary Figure S1A). For control, we used GAPDH exon 1-2 (accession number NM_002046.3), GUSB exon 4-5 (accession number NM_000181.1), OAZ1 (accession number NM 004152.2) and POLR2A (accession number NM_000937.2). Samples were processed using an automated nCounter Sample Prep Station (NanoString Technologies, Inc., Seattle, WA) as previously described [9]. Full probe sets are provided in Supplementary Table S1. Probe designs are described in previous work $[16,17]$.

\section{Validation of nanostring results by quantitative RT-PCR}

RNAs were reverse transcribed using a superscript III first-strand synthesis system (Invitrogen, Carlsbad, CA). For validation of nanostring results, we designed forward primer for exon 13 of MET, GFPT1 F (5'-TGGGTTTTTCCTGTGGCTGAA-3'), reverse primer for exon 15 of MET (5'- GCATGAACCGTTCTGAG ATGAATT-3') and probes overlapping an exon 13-exon 15 junction (5'- AAGCAAATTAAAGATCAGTTTCC-3'). GAPDH gene (ID; Hs99999905_m1) was used as an endogenous control. TaqMan probes were labelled with the reporter dye molecule FAM (6-carboxyfluorescein) at the $5^{\prime}$ end and with TaqMan minor groove binder 
A
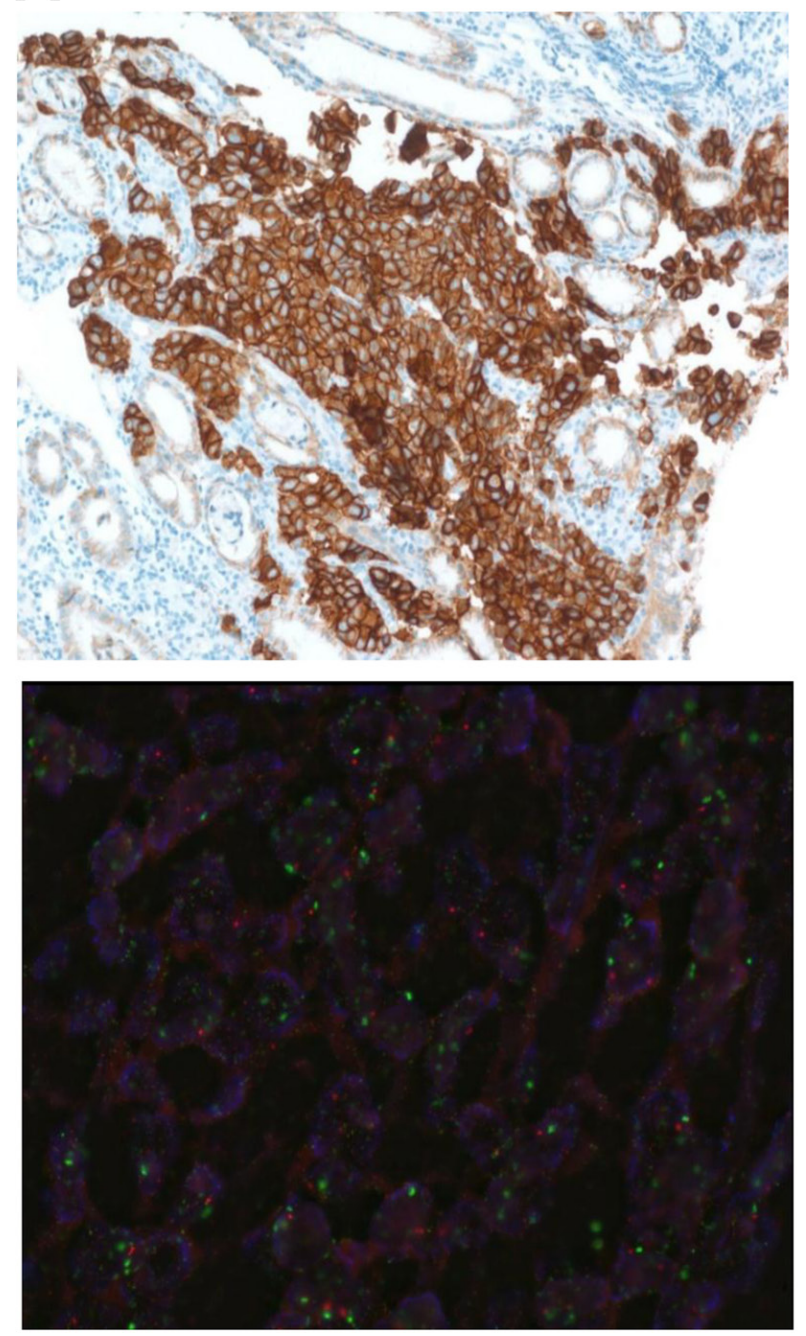

B
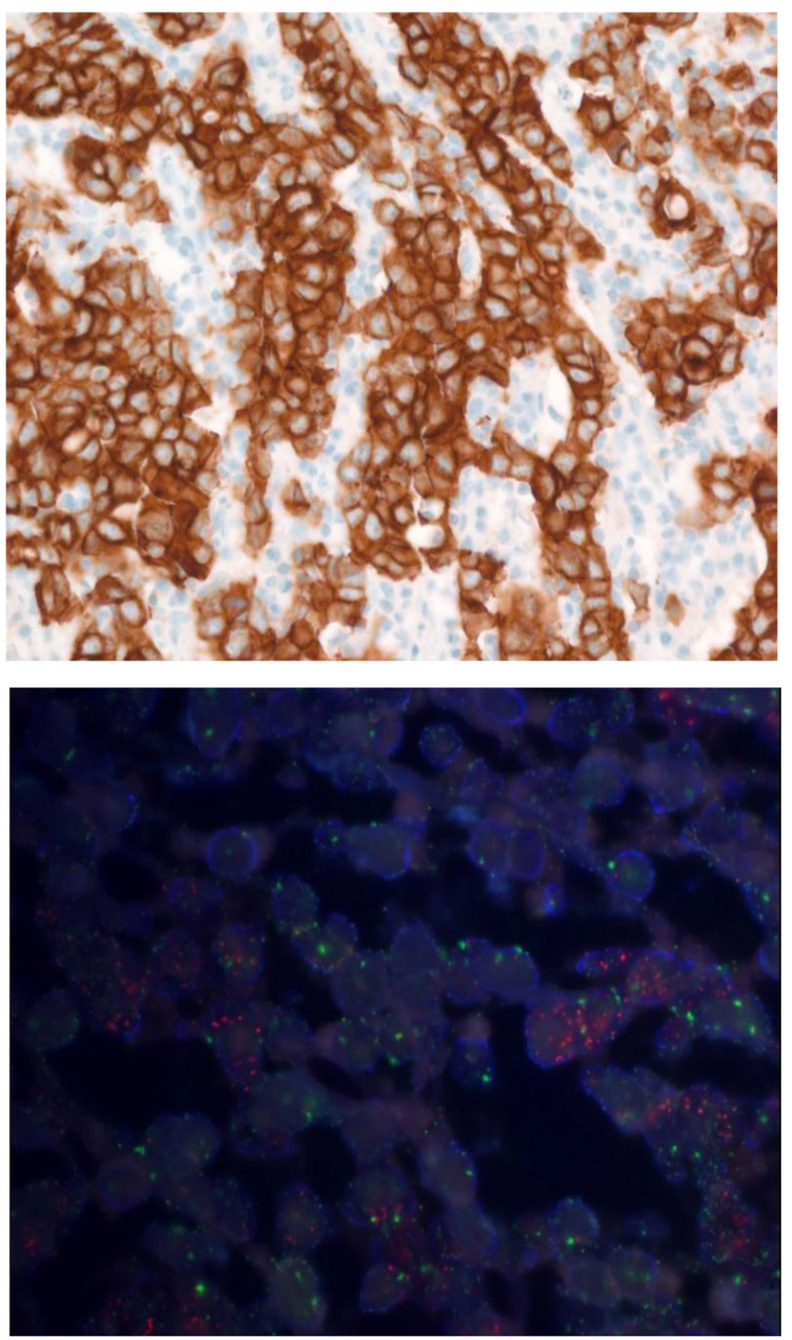

Figure 2: A. METex14+ GC with MET protein overexpression by IHC (upper panel) and no MET amplification by FISH (lower panel) B. METex14+ GC with MET protein overexpression by IHC (upper panel) and concomitant MET amplification by FISH (lower panel).

non-fluorescent quencher (MGB-NFQ) probe at the 3 the 3 in) at the $5^{\prime}$ end and with GATCAGTT TaqMan Universal PCR master mix with AmpErase UNG (Applied Biosystems), $900 \mathrm{~nm}$ primers (forward and reverse), $250 \mathrm{~nm}$ TaqMan probe, and $5 \mu \mathrm{l}$ of cDNA sample in a total reaction volume of $20 \mu \mathrm{l}$. PCR conditions were $95^{\circ} \mathrm{C}$ for $10 \mathrm{~min}$ followed by 40 cycles of amplification at $95^{\circ} \mathrm{C}$ for $15 \mathrm{~s}$ and $60^{\circ} \mathrm{C}$ for $1 \mathrm{~min}$ on the ABI PRISM $7500 \mathrm{HT}$ Fast Real-time PCR. Ct values $<33$ were considered as METex14del+ and $\geq 34$ were negative for METex14del.

\section{Additional validation of nanostring results by CustomDx-Met001}

To validate our results additionally, we used a qRTPCR based kit for detection of alternatively spliced variant of MET to detect METex14del. The kit is intended to detect the presence of alternatively spliced (METex14del) MET transcript in RNA from FFPE tissue sections in accordance with the provided protocol (Custom Diagnostics, Irvine, CA). For the MET WT control, Ct from MET WT P/P mix should be in range between 22 and 28 , and $\mathrm{Ct}$ from METex14del P/P mix should be "undetermined". For the METex14del Control, Ct from MET WT P/P mix should be between 16 and 22; the $\mathrm{Ct}$ from METex14del P/P mix should be between 26 and 32. If the $\mathrm{Ct}$ values for controls fall outside the expected range then that run should not be used for evaluation of test samples.

\section{MET immunohistochemistry}

For MET immunohistochemistry, we used CONFIRM anti-Total MET (SP44) rabbit monoclonal primary antibody (Ventana Medical Systems, Tucson, AZ, USA) with a Ventana BenchMark XT automated slide processing system according to the manufacturer's protocol as previously described $[4,18]$. Both membranous and cytoplasmic staining was scored as follows: 0 , no reactivity or faint staining; $1+$, faint 
A

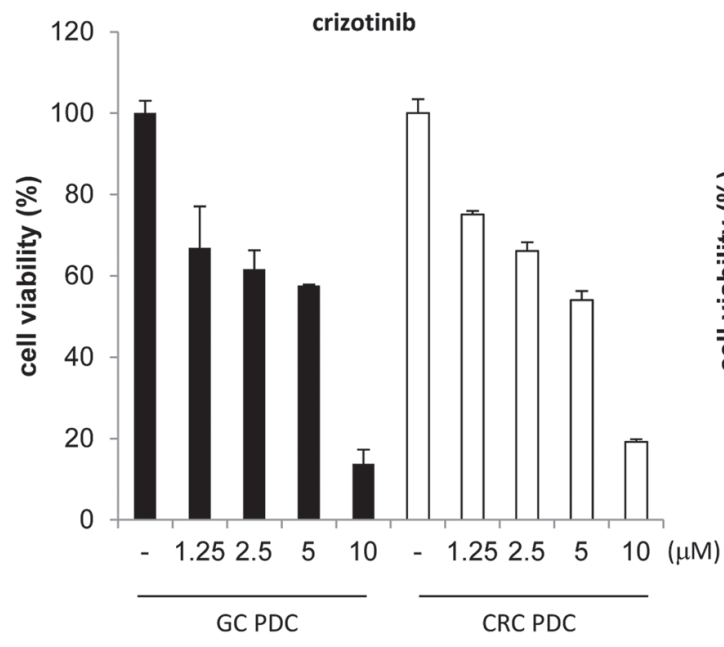

C
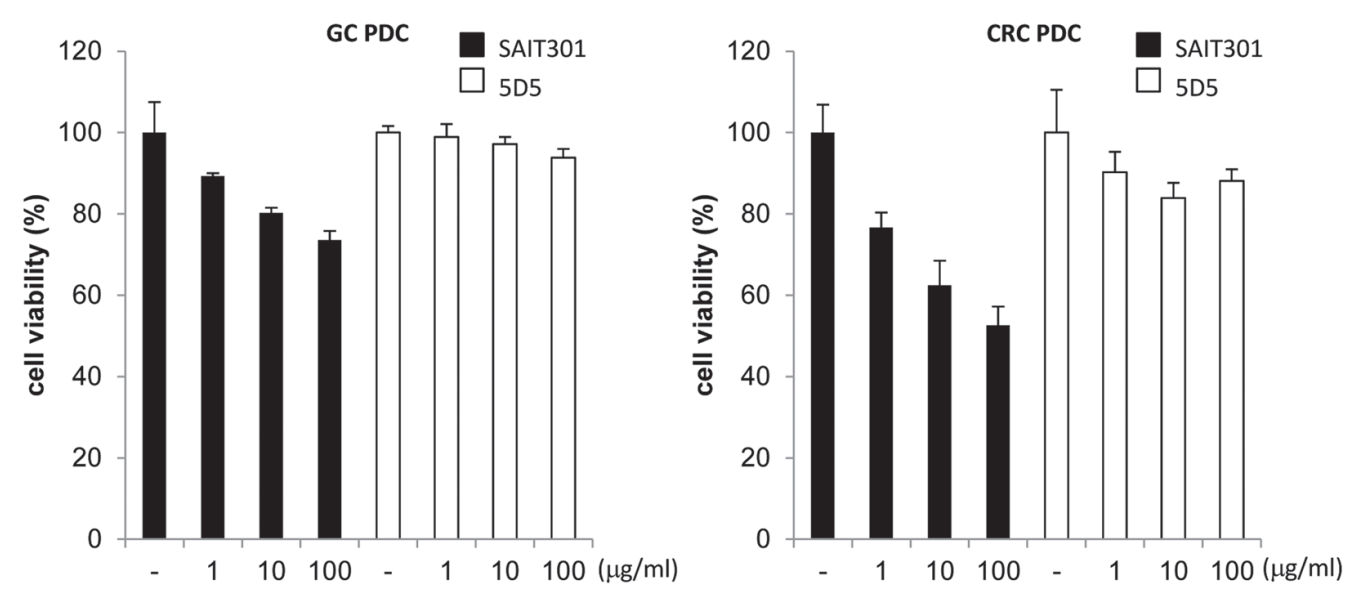

D

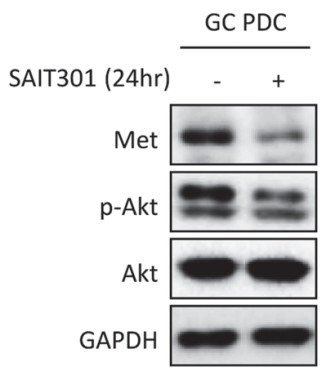

B

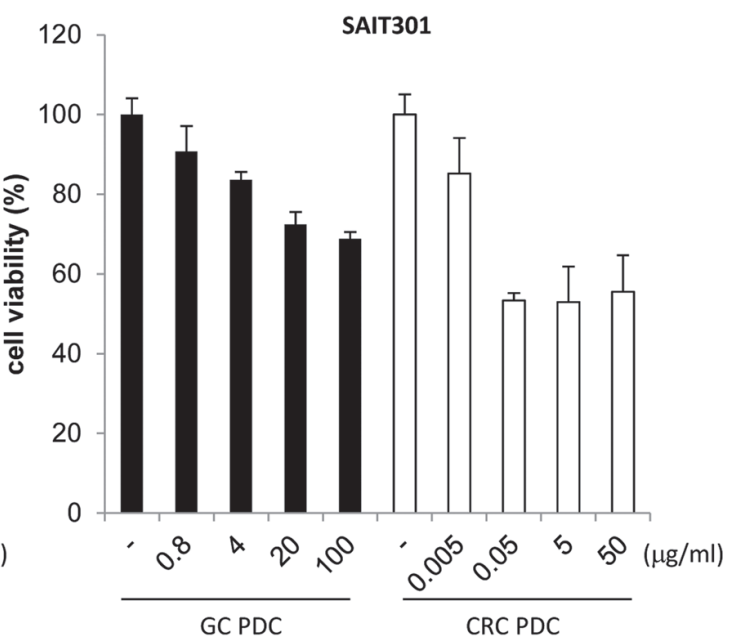

$\mathbf{E}$

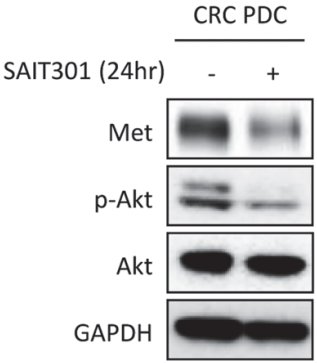

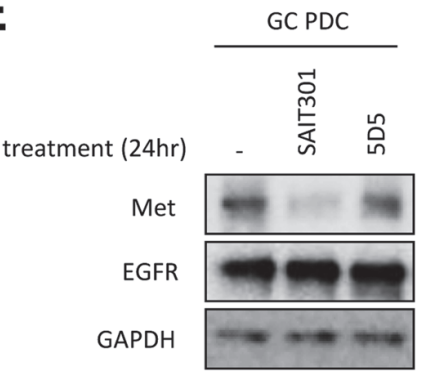

Figure 3: The anti-tumor efficacy of crizotinib and SAIT301 in METex14+ GC and CRC PDCs. A. and B. The viability of METex14+ GC (-) and CRC () PDCs by CTG assay after treating with indicated concentrations of crizotinib (A) and SAIT301 (B) for 5 days. C. The viability of PDCs was measured by CTG assay after treatment with various concentrations of SAIT301 ( $\bullet$ ) and 5D5 ( $\square$ ) for 5 days. The relative cell viability (\%) represents the percent growth as compared to the control group (no treatment). D. The protein levels of MET and p-Akt were measured by Western blot in GC and CRC PDCs after $24 \mathrm{~h}$ treatment of SAIT301. E. The MET protein levels were measured by Western blot in GC PDC after $24 \mathrm{~h}$ treatment of SAIT301 and 5D5.

or weak staining; $2+$, moderate staining; $3+$, strong staining in $>10 \%$ of tumor cells. Membranous alone staining was scored by consensus recommendation on HER2 scoring for gastric carcinoma [19]: 0 , no reactivity; $1+$, faint/barely perceptible membranous reactivity; $2+$, weak to moderate complete or basolateral membranous reactivity; $3+$, moderate to strong complete or basolateral membranous reactivity in $>10 \%$ of tumor cells. MET overexpression was defined as $2+$ or $3+$ by membranous and cytoplasmic interpretation and only $3+$ by membranous interpretation as previously described $[4,18]$. 


\section{Fluorescent and bright-field double in situ hybridization}

FISH was performed using dual-color DNAspecific MET/CEP7 probes (Abnova, Walnut, CA, USA) as described previously [11]. Two pathologists (S.A and M.H) counted the numbers of $M E T$ and chromosome 7 centromere probe (CEP7) signals ( 1 for individual signals, 6 for small clusters and 12 for big clusters) in 20 inter-phase tumor cell nuclei, and the mean number of MET and CEP7 copies per nucleus were determined, along with the ratio. Normal MET/CEP7 signals (one to two copies per cell) in the various non-neoplastic cells served as the internal positive control. We defined $M E T$ gene amplification as a $M E T /$ CEP7 ratio > 2.0 in 20 tumor nuclei and polysomy-7 were regarded as negative for gene amplification.

\section{Immunoblot analysis}

Total proteins from PDCs were isolated using RIPA buffer (Sigma-Aldrich, St. Louis, MO, USA) containing a protease inhibitor cocktail (Roche, Mannheim, Germany) and phosphatase inhibitor cocktail (Roche), and protein concentrations were determined according to Bradford procedure using a Quick Start Bradford Protein Assay (Bio-Rad, Hercules, CA, USA). Thirty $\mu \mathrm{g}$ of proteins were subjected to $10 \%$ SDS-polyacrylamide gel electrophoresis, and electro-transferred onto nitrocellulose membranes. The membranes were blocked with $5 \%$ nonfat dry milk in Tris-buffered saline containing $0.1 \% \mathrm{v} / \mathrm{v}$ Tween 20 , and probed overnight at $4{ }^{\circ} \mathrm{C}$ with a Specific antibodies: pMET (Tyr 1234/1235), pAkt (Ser473), Akt(C67E7), pERK1/2 (Thr202/Tyr204), ERK1/2 (Thr202/Tyr204), GAPDH from Cell Signaling Technology (Beverly, MA, USA), and MET from Abcam (Abcam, Cambridge, UK) and MET (C-28) from Santa Cruz biotechnology (Santa Cruz, CA, USA), and beta actin from Sigma Aldrich. Horseradish peroxidase-conjugated anti-rabbit or mouse $\mathrm{IgG}$ (Vector, Burlingame, CA, USA) were used as a secondary antibody, and signals were detected by chemiluminescence using ECL Western Blotting Substrate (Thermo Scientific, Rockford, IL, USA), and visualized by using LAS-4000 (Fujifilm, Tokyo, Japan).

\section{Reagents}

SAIT301 was produced using a recombinant $\mathrm{CHO}$ stable cell line [20]. Crizotinib, PHA-665752, XL-184 and lapatinib were purchased from Selleck Chemicals (Houston, TX, USA).

\section{Patient derived tumor cell culture and cell proliferation inhibition assay}

Patient derived tumor cells (PDCs) were isolated from malignant effusions, surgical tissues or biopsies after obtaining informed consent form (the SMC Oncology
Biomarker study (NCT\#01831609, clinicaltrials.gov). The protocol was approved by the Institutional Review Board at Samsung Medical Center. The cells were cultured in RPMI media supplemented with $10 \%$ fetal bovine serum, $0.5 \mu \mathrm{g} / \mathrm{ml}$ of hydrocortisone (Sigma Aldrich), 5 $\mu \mathrm{g} / \mathrm{ml}$ of insulin(PeproTech, Rocky Hill, NJ, USA), 5 ng of EGF and FGF (PeproTech). Cell proliferation in response to antibody treatment in vitro was assessed by a CTG (Promega, Madison, WI, USA) assay according to manufacturer instructions. Cells were plated at a density of $5 \times 10^{5}$ cells in FBS 10\% (v/v) RPMI 1640 medium onto a 96-well plate (BD Biosciences, Palo Alto, CA, USA). After $24 \mathrm{~h}$ incubation, treated antibodies or small molecules diluted in $10 \%$ FBS (v/v) RPMI medium were added. After 5 days incubation, $100 \mu \mathrm{l}$ of the CTG reagent was added to each well followed by incubation at RT for $30 \mathrm{~min}$. The luminescence signal was recorded using Envision 2104 Multi-label Reader (Perkin Elmer, Foster City, CA, USA).

\section{DISCUSSION}

The Met proto-oncogene is encoded by 21 exons spanned by 20 introns [7]. The transmembrane domain of MET is encoded by the whole of exon 13 and part of exon 14. Met exon 14 deletion thus results in an in frame deletion of 47 amino acids in the juxtamembrane region which contains the domain. The MET deletion mutant, while displaying decreased $\mathrm{Cbl}$ binding, leads to prolonged protein stability, extended cell signaling on ligand stimulation, and increased tumorigenicity [9]. The incidence of METex14del was estimated to be $3.5 \%$ in NSCLC [5] and 1.9\% in neuroblastoma [11]. Recently, analysis of tumor genomic profiles from 38,028 patients identified 221 cases with METex14 mutations $(0.6 \%)$, including 126 distinct sequence variants in lung adenocarcinoma $(3.0 \%)$, other lung neoplasms $(2.3 \%)$, brain glioma $(0.4 \%)$, and tumors of unknown primary origin (0.4\%) [21]. To date, METex14del has not been reported in either gastric or colon cancer patients. This is the first report that identified METex 14del at a frequency of approximately $5 \%$ in both gastric and colon cancer in addition to NSCLC. All METex14del+ cases also over-expressed MET protein with only one case showed $M E T$ amplification consistent with the hypothesis that METex14del leads to MET over-expression without the need for concurrent $M E T$ amplification. In addition, METex14del occurs exclusively to ALK, ROS1, NTRK1, NTRK3 or RET fusions indicating METex14del is likely a driver mutation and defines a unique molecular subset of gastric and colon cancers.

In GC, only Hs746T cell line exhibited both splice-site mutations and MET amplification with MET protein overexpression [9]. We are the first group to report on three GC cases (4.8\%) with METex14del and strong MET protein overexpression by IHC. We 
performed MET exon 14 Sanger sequencing with gDNAs and cDNAs, but failed to detect mutations in our GI METex14del+cancer samples (data not shown). Given the low sensitivity of Sanger sequencing $(<12 \%)$ and low Ct values in our RT-PCR results, we postulate that METex14del+ tumor population is present in small subpopulation of tumors. Furthermore, we also report c. $3082+811$ A TTTTAACA > GGTTTGAT mutations on intron 14 region of $M E T$ with variant allele frequencies around $10 \%$. This intronic mutation is a novel mutation, which has not been reported in COSMIC and TCGA lung adenocarcinomas (Supplementary Table S2). We found that this mutation site is important where proteins including well known splicing factors such as Jun, and Fox, etc. bind. ChIP-Seq dataset of ENCODE project provides strong evidences and the specific intronic mutation site reported here exists in the middle of the protein binding sites (Supplementary Figure S5). We assume that this $8 \mathrm{bp}$ mutation on this binding site would affect decreased protein binding affinity of these proteins and may cause exon 14 skipping in small subpopulations of tumor, especially given the tumor heterogeneity in GI cancer.

In two PDC cell lines with METex14del+ without concurrent $M E T$ amplification, tumor growths were profoundly inhibited by both MET tyrosine kinase inhibitors and a MET targeting monoclonal antibody-. Our study is the first proving efficacy of MET inhibitors or monoclonal antibody in human GI PDC lines with METex14del that over-expressed MET but did not have MET amplification. Furthermore the in vitro cell line inhibition data indicated that METex14del is potentially an actionable driver mutation in GI malignancies. This finding provides new opportunities for clinical trials on MET inhibitors in metastatic GC to include not only MET amplified GC, but also MET over-expressed, MET non-amplified and METex14del+ GC. So far all METex14del+ cases had concurrent MET over-expression, it remained to be determined if $M E T e x 14 d e l$. Now, we developed screening algorithm to detect METex $14 \mathrm{del}$ for screening oncology patients. First, we screen MET overexpression by IHC and select MET-positive $(\geq 2+)$ cases. ${ }^{4}$ In IHC-positive cases, we perform FISH to exclude $M E T$ amplification as a cause of MET overexpression. In cases without MET amplification, we perform custom-designed and RTPCR using mRNAs from tumor to detect METex14del transcripts. For RT-PCR positive cases, we sequence them to find underlying cause of METex 14 alterations at the DNA level.

In summary this report supports that the aberration in Cbl-mediated negative regulation of MET can indeed result in MET protein overexpression and subsequent addiction of tumor cells to MET signaling and may serve as an actionable driver mutation in a subset of GI malignancies.

\section{ACKNOWLEDGMENTS}

We would like to thank Dr. James Christensen at Mirati Therapeutics, San Diego, California for his helpful scientific advises.

\section{CONFLICTS OF INTEREST}

The authors declare no conflicts of interest.

\section{FUNDING}

This study was supported by a grant from the 20 by 20 project of Samsung Medical Center (GF01140111). This research was supported by a grant of the Korea Health Industry Development Institute (KHIDI), funded by the Ministry of Health \& Welfare, Republic of Korea (grant number: HI14C2188 to Jeeyun Lee; grant number: HI14C3418 to J.M.L, B.K, J.C, K.K, Y.S.P and J.L).

\section{REFERENCES}

1. Ferracini R, Longati P, Naldini L, Vigna E, Comoglio PM. Identification of the major autophosphorylation site of the Met/hepatocyte growth factor receptor tyrosine kinase. J Biol Chem. 1991; 266:19558-19564.

2. Jardim DL, Tang C, Gagliato Dde M, Falchook GS, Hess K, Janku F, Fu S, Wheler JJ, Zinner RG, Naing A, Tsimberidou AM, Holla V, Li MM, et al. Analysis of 1, 115 patients tested for MET amplification and therapy response in the MD Anderson Phase I Clinic. Clin Cancer Res. 2014; 20:6336-6345.

3. Lennerz JK, Kwak EL, Ackerman A, Michael M, Fox SB, Bergethon K, Lauwers GY, Christensen JG, Wilner KD, Haber DA, Salgia R, Bang YJ, Clark JW, et al. MET amplification identifies a small and aggressive subgroup of esophagogastric adenocarcinoma with evidence of responsiveness to crizotinib. J Clin Oncol. 2011; 29:4803-4810.

4. Ha SY, Lee J, Kang SY, Do IG, Ahn S, Park JO, Kang WK, Choi MG, Sohn TS, Bae JM, Kim S, Kim M, Kim S, et al. MET overexpression assessed by new interpretation method predicts gene amplification and poor survival in advanced gastric carcinomas. Mod Pathol. 2013; 26:1632-1641.

5. Kong-Beltran M, Seshagiri S, Zha J, Zhu W, Bhawe K, Mendoza N, Holcomb T, Pujara K, Stinson J, Fu L, Severin C, Rangell L, Schwall R, et al. Somatic mutations lead to an oncogenic deletion of met in lung cancer. Cancer Res. 2006; 66:283-289.

6. Lee JM, Kim B, Lee SB, Jeong Y, Oh YM, Song YJ, Jung S, Choi J, Lee S, Cheong KH, Kim DU, Park HW, Han YK, et al. Cbl-independent degradation of Met: ways to avoid agonism of bivalent Met-targeting antibody. Oncogene. 2014; 33:34-43. 
7. Seo JS, Ju YS, Lee WC, Shin JY, Lee JK, Bleazard T, Lee J, Jung YJ, Kim JO, Shin JY, Yu SB, Kim J, Lee ER, et al. The transcriptional landscape and mutational profile of lung adenocarcinoma. Genome Res. 2012; 22:2109-2119.

8. Cancer Genome Atlas Research Network . Comprehensive molecular profiling of lung adenocarcinoma. Nature. 2014; 511:543-550.

9. Zang ZJ, Ong CK, Cutcutache I, Yu W, Zhang SL, Huang D, Ler LD, Dykema K, Gan A, Tao J, Lim S, Liu Y, Futreal PA, et al. Genetic and structural variation in the gastric cancer kinome revealed through targeted deep sequencing. Cancer Res. 2011; 71:29-39.

10. Asaoka $\mathrm{Y}$, Tada $\mathrm{M}$, Ikenoue $\mathrm{T}$, Seto $\mathrm{M}$, Imai $\mathrm{M}$, Miyabayashi K, Yamamoto K, Yamamoto S, Kudo Y, Mohri D, Isomura Y, Ijichi H, Tateishi K, et al. Gastric cancer cell line Hs746T harbors a splice site mutation of c-Met causing juxtamembrane domain deletion. Biochem Biophys Res Commun. 2010; 394:1042-1046.

11. Yan B, Lim M, Zhou L, Kuick CH, Leong MY, Yong KJ, Aung L, Salto-Tellez M, Chang KT. Identification of MET genomic amplification, protein expression and alternative splice isoforms in neuroblastomas. J Clin Pathol. 2013; 66:985-991.

12. Christensen JG, Zou HY, Arango ME, Li Q, Lee JH, McDonnell SR, Yamazaki S, Alton GR, Mroczkowski B, Los G. Cytoreductive antitumor activity of PF-2341066, a novel inhibitor of anaplastic lymphoma kinase and c-Met, in experimental models of anaplastic large-cell lymphoma. Mol Cancer Ther. 2007; 6:3314-3322.

13. McDermott U, Iafrate AJ, Gray NS, Shioda T, Classon M, Maheswaran S, Zhou W, Choi HG, Smith SL, Dowell L, Ulkus LE, Kuhlmann G, Greninger P, et al. Genomic alterations of anaplastic lymphoma kinase may sensitize tumors to anaplastic lymphoma kinase inhibitors. Cancer Res. 2008; 68:3389-3395.

14. Settleman J. Cell culture modeling of genotype-directed sensitivity to selective kinase inhibitors: targeting the anaplastic lymphoma kinase (ALK). Semin Oncol. 2009; 36:S36-41.
15. Yakes FM, Chen J, Tan J, Yamaguchi K, Shi Y, Yu P, Qian F, Chu F, Bentzien F, Cancilla B, Orf J, You A, Laird AD, et al. Cabozantinib (XL184), a novel MET and VEGFR2 inhibitor, simultaneously suppresses metastasis, angiogenesis, and tumor growth. Mol Cancer Ther. 2011; 10:2298-2308.

16. Lira ME, Choi YL, Lim SM, Deng S, Huang D, Ozeck M, Han J, Jeong JY, Shim HS, Cho BC, Kim J, Ahn MJ, Mao M. A single-tube multiplexed assay for detecting ALK, ROS1, and RET fusions in lung cancer. J Mol Diagn. $2014 ; 16: 229-243$.

17. Lee J, Sohn I, Do IG, Kim KM, Park SH, Park JO, Park YS, Lim HY, Sohn TS, Bae JM, Choi MG, Lim do H, Min BH, et al. Nanostring-based multigene assay to predict recurrence for gastric cancer patients after surgery. PLoS One. 2014; 9:e90133.

18. Ha SY, Lee J, Jang J, Hong JY, Do IG, Park SH, Park JO, Choi MG, Sohn TS, Bae JM, Kim S, Kim M, Kim S, et al. HER2-positive gastric cancer with concomitant MET and/or EGFR overexpression: a distinct subset of patients for dual inhibition therapy. Int J Cancer. 2015; 136:1629-1635.

19. Hofmann M, Stoss O, Shi D, Buttner R, van de Vijver M, Kim W, Ochiai A, Ruschoff J, Henkel T. Assessment of a HER2 scoring system for gastric cancer: results from a validation study. Histopathology. 2008; 52:797-805.

20. Oh YM, Song YJ, Lee SB, Jeong Y, Kim B, Kim GW, Kim KE, Lee JM, Cho MY, Choi J, Nam DH, Song PH, Cheong KH, et al. A new anti-c-Met antibody selected by a mechanism-based dual-screening method: therapeutic potential in cancer. Mol Cells. 2012; 34:523-529.

21. Framton GM, Ali SJ, Rosenzweig M, Chmielecki J, Lu X, Bauer TM, Akimov M, Bufill J, Lee C, Jentz D, Hoover R, et al. Activation of MET via diverse exon 14 splicing alterations occurs in multiple tumor types and confers clinical sensitivity to MET inhibitors. Cancer Discovery. 2015; Published OnlineFirst May 13, 2015. 